\title{
Union Effects on Product and Technological Innovation
}

\author{
Alex Bryson ${ }^{a}$ \\ ${ }^{a} \mathrm{UCL}$ and IZA \\ University College London, London, UK \\ a.bryson@ucl.ac.uk \\ and \\ Harald Dale-Olsen ${ }^{\mathrm{b}}$ \\ 'Institutt for samfunnsforskning, and IZA \\ Institutt for samfunnsforskning, Oslo, Norway \\ hdo@socialresearch.no
}

\begin{abstract}
We present theoretical and empirical evidence challenging early studies that found unions were detrimental to workplace innovation. Under our theoretical model, unions prefer product innovation to labour-saving technological process innovation, thus making union wage bargaining regimes more conducive to product innovation than competitive pay setting. We test the theory with population-representative workplace data for Britain and Norway. We find strong support for the notion that local bargaining leads to product innovation, either alone or together with technological innovation.
\end{abstract}

Key-words: product innovation; process innovation; trade unions; collective bargaining

JEL codes: J28; J51; J81; L23

Declarations of interest: none.

Funding: This work was supported by the Norwegian Research Council grants No. 202647 and No. 295914.

Corresponding author: Harald Dale-Olsen, hdo@socialresearch.no.

Acknowledgement: We thank the Editors of Research in Labor Economics and two anonymous referees, participants at the 2015 Royal Economic Society Conference in Manchester and the 2016 European Association of Labour Economics in Ghent for comments on an earlier draft of this paper. Alex Bryson thanks the sponsors of the Workplace Employment Relations Survey 2011 (Department for Business, Energy and Industrial Strategy, Acas, ESRC and NIESR) and the UK Data Archive for access to the WERS data. 


\section{INTRODUCTION}

Innovation is an important source of productivity growth (Grossman and Helpman, 1991; Cummins and Violante, 2002; OECD, 2003; Griffith et al., 2004; Aghion and Howitt, 2007) which is why a vast literature examines factors that inhibit and promote innovation, including research and design $(\mathrm{R} \& \mathrm{D})$ expenditure, patents and technological diffusion. One strand of this literature considers the role played by trade unions. Trade unions have a strong interest in firms' ability to innovate because innovation can affect labour demand - either positively via product innovation, or negatively where capital investments substitute for labour - and it offers opportunities for rent extraction. In their review of the literature Menezes-Filho and Van Reenen (2003) - henceforth MFVR - suggest the emerging evidence points to unions reducing R\&D expenditure in the United States, but not in Western Europe. However, they argue evidence on links between unionisation and other aspects of innovation is less clear cut and that "there is...a need to expand the samples of countries under study that are still very Anglo-Saxon biased" (p. 329). This remains the case today.

Our contribution to the literature is three-fold. First, we build on the theoretical insights from Lommerud and Straume (2012) to show that unions might have preferences for and thus influence the product and technological innovation processes at firms. Throughout, we emphasise the distinction between product and labour-saving technological process innovation (Lin and Saggi, 2002) $)^{1}$, an important distinction given the recent theoretical contributions focusing on links between union structure and product innovation (Basak and Mukherjee, 2018), and the previous studies emphasizing the relationship between these different kinds of innovation and the intensity of competition (Bonanno and Haworth, 1998). This distinction between innovation types within the firm contrasts with the approach of Beladi and Mukherjee (2017) which, by introducing sub-contracting and outsourcing, makes it possible to avoid the union and its direct influence on innovations.

\footnotetext{
1 Although product innovation accounts for two-thirds of all R\&D investment in the U.S. the theoretical literature largely focused on process innovation until Lin and Saggi (2002).
} 
Second, we show that, under plausible assumptions, local union wage bargaining can be more conducive to product innovation than purely competitive wage setting.

Third, we test this proposition empirically with comparable workplace data for Britain and Norway, thus answering MFVR's call for more empirical analysis from beyond the Anglo-Saxon world. Britain and Norway are similar with respect to technology use and competitiveness (WEF, 2013) and innovations and R\&D levels (OECD, 2007: Figure 5.9), at least before the financial crisis. But they differ in terms of unionization (OECD, 2017). Norway is characterised by centralised, coordinated collective bargaining combining sectoral and local agreements. Britain is far less unionised and where unions exist they do so at plant or organization level. However, our focus is not to draw distinctions between countries, but rather use within country relationships between unionisation and innovation to show the value of local level unionisation - regardless of differences in union institutions, and regardless of any differences in levels of innovation across countries. $^{2}$

The remainder of the paper is structured as follows. Section II reviews the previous theoretical and empirical literatures linking innovation to unionisation. Section III presents the key insight from a theoretical model of union wage structures, product and labour-saving technological process innovation. Section IV outlines the empirical strategy. Section V describes our data and key measures. Section VI describes the relationship between bargaining, unionisation and employer organisation, while Section VII reports our main results on unionisation and innovation. Section VIII concludes. The theoretical model of union wage structures, product and laboursaving technological process innovation is presented in detail in the appendix.

\footnotetext{
${ }^{2}$ However, we explicitly take into account industry differences and geographical markets (exports). Recent literature point to industry-specific demand and cost linkages which affect the returns to different kinds of innovations. Flach and Irlacher (2018) find that in differentiated industries, cannibalization is lower and firms invest more in product innovation, while in homogeneous industries, firms internalize intra-firm spillovers and invest more in process innovation. Exploiting variation induced by large exchange rate devaluations, they find that access to foreign markets increases the innovation incentives.
} 


\section{PREVIOUS LITERATURE}

\section{Theory}

The literature portrays trade unions as agents distorting relative prices via wage bargaining and "featherbedding" thus increasing firms' labour costs, reducing their profitability and investment activity (Oswald, 1985; Hirsch, 1992; Johnsen, 1990). This view has received some empirical support (Menezes-Filho, 1997), but it is also contested since it ignores the potential value of union 'voice'. Through voice mechanisms unions can reduce worker grievances, lower worker turnover - and the associated labour costs - thus raising tenure and firms' incentives to invest in human capital, all of which can increase productivity (Freeman and Medoff, 1984). Another literature has emerged noting that the structure of collective bargaining differs between countries and is important for productivity and innovation (Agell and Lommerud, 1993; Moene and Wallerstein, 1997; Haucap and Wey, 2004; Braun, 2011; Barth et al., 2015). ${ }^{3}$

The early literature on unions and innovation focused on the "hold-up" problem (Grout, 1984; Malcomson, 1997) whereby unions seek to capitalise on firm sunk investments such as R\&D to negotiate higher wages. This, in turn, may result in shareholder underinvestment if bargaining is not efficient. ${ }^{4}$ Any underinvestment effect of unions, however, could be offset under conditions of oligopolistic competition where the strength of unions, coupled with the market structure, provide stronger incentives for innovation than under a competitive model (Ulph and Ulph, 1994, 1998, 2001). While the wage level hold-up problem has been known for a long time, Haucap and Wey (2004) identified a new source of hold-up problem, namely wage differentiation hold-up: as

\footnotetext{
${ }^{3}$ Our study focus on innovations. There is a huge literature on the impact of bargaining and bargaining level on wages, unemployment and other outcomes, and these are of course related. Calmfors and Driffill's (1988) classical work argued that both heavily centralised bargaining regimes and competitive regimes outperform regimes in the middle in terms of employment. More recent work shows that firm-level bargaining is actually superior to sectoral bargaining with regards to unemployment (Jimeno and Thomas, 2013) and that two-tier bargaining (i.e., also local bargaining) is superior to sectoral bargaining in relation to capital investment (Cardullo et al., 2020). Similarly, even if rent-sharing is introduced, which diminishes the differences, wages are always higher when determined at the firm-level compared to at the sectoral level (dePinto, 2019).

${ }^{4}$ An optimal solution may still be achieved if bargaining is efficient, that is to say, if bargaining occurs over investments in addition to wages. Furthermore, the sequential bargaining framework of Manning (1987a. 1987b) shows that although efficiency might be achieved in Grout's setting if the bargaining solution is equal at all stages as a special case, inefficiency is equally likely and might arise for example due to differences within the bargaining structure.
} 
the wage differential between firms increases, the profit of the innovating firm decreases. Finally, Beladi and Mukherjee (2017) show that the negative relationship between union power and innovations might not hold where the firm outsources production to other firms, thus allowing the firm to avoid the union.

In Haucap and Wey's (2004) Cournot duopoly model the payoff from innovation is larger for a highly productive firm under centralised wage setting than under local wage bargaining. This provides incentives both for process innovation and, as other studies have shown (Moene and Wallerstein, 1997; Barth et al., 2014), for job creation and employment. By contrast, firm level bargaining allows less productive firms to stay in the market and reduces average productivity. By incorporating collective bargaining into the heterogeneous firm productivity model of Melitz and Ottaviano (2008), Braun (2011) shows that sectoral bargaining is also associated with lower prices on average and less product variety than firm-level bargaining. If product variety is interpreted as the consequence of product innovation, this study then contrasts with Haucap and Wey in that local bargaining induces more innovation than collective bargaining. ${ }^{5}$ Similar findings are also provided by Basak and Mukherjee (2018): based on a Cournot duopoly model, they show the gains from product innovation are larger under local bargaining than under sectoral collective bargaining if products are symmetrically differentiated. However, where products are asymmetrically differentiated the opposite is the case.

Finally, Lommerud and Straume (2012) take into account unions' incentives to endorse or oppose labour saving technologies and firms' incentives to invest in these. As employment protection declines, unions become less willing to endorse labour saving technologies due to the risk of job loss. However, higher reservation wages make unions more willing to accept technological change. In this sense the paper is in the spirit of Acharya et al. (2014) who show that wrongful discharge laws, i.e., laws that protect employees against unjust dismissal, spur innovation

\footnotetext{
${ }^{5}$ Product variation might imply product differentiation in quality (vertical product differentiation) or differentiation in the number of products (horizontal differentiation). Empirically Khandelwal (2010) has identified substantial heterogeneity in product markets' scope for quality differentiation.
} 
and new firm creation. Wrongful discharge laws are clearly related to the employment protection legislation of workers.

\section{Empirical evidence}

MFVR (2003) reviewed 31 studies on the impact of unionism on different innovation measures. Results are mixed. European studies diverge from their U.S. counterparts, and the sign of the raw correlations between unionism and innovation depends on the innovation measure (R\&D intensity, the output of R\&D and technology diffusion). For example, in the UK technological diffusion is unrelated to unionism conditioning on other factors (MFVR, 2003: 315, 326-327), although the raw correlations are positive. $\mathrm{R} \& \mathrm{D}$ intensity is negatively related to unionisation in the U.S., but unrelated in Germany and the UK. The authors speculate that the differences may arise from U.S. unions' focus on wages (2003:328), whereas European unions may give greater consideration to the employment consequences of their bargaining.

The recent empirical literature on the relationship between innovation and unionism is rather scarce and results are mixed. In their meta-analysis, Doucouliagos and Laroche (2013) draw inferences from 28 studies using different union measures, innovation measures and empirical strategies. Their main results indicate that unions and innovations are negatively related, that this negative relationship is stronger in labour markets with weak regulation, but that this relationship is weakening over time. Using a regression discontinuity design for firms in the United States Bradley et al. (2016) find new unionization reduces patent quality and quantity, resulting in firms shifting their innovation activities away from states where unions are successful in organising. For Germany Addison et al. (2017) finds unionism does not retard innovation, and that sectoral collective bargaining might even be pro-innovative. In a similar vein, Vernon and Rogers (2013) provide empirical support for the notion that union strength in industrial unionism promotes productivity growth. For the UK, which is characterised by fragmented local bargaining and very little sectoral bargaining, Bryson et al. (2013) find that organizational changes akin to process 
innovations are associated with increased job-related anxiety and lower job satisfaction, but that the negative effects of organizational change on employee job-related anxiety are ameliorated when employees work in a unionised workplace and are involved in the introduction of the changes. This latter finding indicates that the implementation costs under local union pay setting can be lower than under other regimes.

\section{THEORETICAL MOTIVATION}

We take Lommerud and Straume's (2012) 2-period model as a starting point but depart from it in three important ways. First, we ignore costs associated with employment protection (this will be addressed later), making it costless for firms to adjust second period employment. This makes it possible to analyse equilibrium outcomes in the second period only, since the period-specific solutions are independent of each other. Second, we introduce product innovation into the model and, thirdly, we extend the model to incorporate heterogeneous implementation costs. The model is presented in Appendix, but the key insight is discussed here as the basis for the empirical analyses that follow.

In the model, we differentiate between two kinds of technologies: labour-saving technologies and product innovation. Labour-saving technology increases union wages, but employment is lower. Ignoring the issue of implementation costs, firms always profit from laboursaving technologies. If unions have a strong preference for employment, unions actually might experience a utility loss from labour-saving technologies. Thus, unions might not endorse laboursaving technologies, and might actively increase the implementation costs associated with these.

Product innovation increases union wages and yields increased employment. Firms always profit from product innovation (ignoring implementation costs). Regardless of employment preferences, unions experience a utility gain from product innovations, and they thus endorse such innovations. 
What happens when product and labour-saving innovations are jointly introduced? As in the two previous innovation cases, union wages and firm profits increase. However, in contrast to the case of labour-saving innovations only, increased employment might actually follow from these two innovations jointly, if they are of equal size. Similarly, depending on the size of the innovations and regardless of employment preferences, unions might experience a utility gain from both innovations. Thus, although unions might not endorse labour-saving technologies alone, they might accept these if they are combined with product innovations.

Our analysis cannot reveal whether innovations are more likely to occur under competitive wage setting than union wage setting. If the implementation costs do not differ between competitive and union firms, then competitive firms should have a higher willingness to pay for innovations than union firms, and thus both kinds of innovations should be more likely to occur here. However, since unions are not indifferent regarding the different kinds of innovations, they might influence the implementation costs. In particular, this is true for product innovations, which our model clearly indicates unions endorse. Thus, the implementation cost differences might turn the innovation incentives around, implying that union wage setting is more conducive for innovations than competitive wage setting.

Which effect dominates is an empirical question. However, if the empirical analysis reveals that innovations occur more frequently among union firms, then this will be a strong indication of lower implementation costs among union firms than competitive firms.

In our model, we have abstracted away from uncertainties regarding the innovations, other labour market traits such as employment protection and minimum wages, and we only let unions affect firm performance through their preferences as expressed during local wage bargaining. Admittedly, unions might influence firm performance along numerous dimensions, such as the probabilities of achieving a specific innovation. For firms to innovate, the expected net gain from innovating (expected profit gain less implementation costs) has to exceed the expected net gain from abstaining from innovations. From Lommerud and Straume (2012), which our theoretical work is 
based upon, we already know that in these models, stricter EPL decreases firms' incentives for technology adoption, and since stricter EPL reduces the downside of the labour-saving technology (probability of job loss goes down), unions will endorse product innovation less.

Furthermore, unions might bargain for wages on a sectoral or higher level and not locally. On one hand, from Haucap and Wey (2004), we know that under certain assumptions sectoral bargaining might, but does not have to, yield higher incentives for innovations than a competitive solution. On the other hand, from Basak and Mukherjee (2018) we know that if products are symmetrically differentiated, then local wage bargaining might yield higher incentives for product innovation than sectoral bargaining. Empirically we conduct robustness checks to test the importance of the bargaining level.

\section{EMPIRICAL STRATEGY}

To test the relationship between innovations and union wage bargaining, our starting model is a standard bivariate Probit model. This can be defined as follows:

$$
\begin{array}{ll}
\Phi^{*}=\mathrm{X}^{\prime} \beta_{\Phi}+\alpha_{\Phi} \text { Bargaining }+\varepsilon_{1}, & \Phi=\mathrm{I}\left(\Phi^{*}>0\right), \\
\text { 1) } \Gamma^{*}=\mathrm{X}^{\prime} \beta_{\Gamma}+\alpha_{\Gamma} \text { Bargaining }+\varepsilon_{2}, & \Gamma=\mathrm{I}\left(\Gamma^{*}>0\right),
\end{array}
$$

where $\Phi^{*}$ and $\Gamma^{*}$ express the latent variables associated with product innovation and new production technology, respectively, I( . ) denotes the indicator function, X expresses a control vector, while Bargaining expresses a dummy taking the value of 1 if bargaining occurs at the workplace. In addition, we assume that $\left(\varepsilon_{1}, \varepsilon_{2}\right)$ is drawn from a standard bivariate Probit distribution, i.e.,

$$
\text { 2) }\left(\varepsilon_{1}, \varepsilon_{2}\right) \sim \mathrm{N}\left(\left[\begin{array}{l}
0 \\
0
\end{array}\right],\left[\begin{array}{ll}
1 & \rho \\
\rho & 1
\end{array}\right]\right) \text {. }
$$

If bargaining can be treated as exogenous with respect to innovations (potentially a strong assumption), then equations 1) and 2) will allow consistent estimation of the $\alpha$ 's. We assume that it is workers, rather than employers, who demand union bargaining. In Norway, if the workers 
meet the threshold to trigger bargaining the employer is legally obliged to enter bargaining. ${ }^{6}$ In the UK this is more dependent on employer preferences, but still the basic assumption that it is workers who demand bargaining appears reasonable. ${ }^{7}$ Thus bargaining might be endogenous in an innovation regression, if these unionised workers demanding bargaining rights might differ in productivity (capacity for innovations) or the demand for unionisation vary with the way employers seek to innovate. Employers might be members of employer organisations (EO) regardless of whether bargaining occurs. EO-membership, as a demand side characteristic, is not directly associated with product innovation nor the introduction or upgrading of new production technology.

Thus, to take account of the potential endogeneity of bargaining, we treat bargaining as a stochastic but recursively determined variable and let variation across employers in employer organisation membership affect the probability of wage bargaining (but not innovations). This can be defined as follows:

$$
\begin{array}{ll}
\Phi^{*}=\mathrm{X}^{\prime} \beta_{\Phi}+\alpha_{\Phi} \text { Bargaining }+\varepsilon_{1}, & \Phi=\mathrm{I}\left(\Phi^{*}>0\right), \\
\text { 3) } \Gamma^{*}=\mathrm{X}^{\prime} \beta_{\Gamma}+\alpha_{\Gamma} \text { Bargaining }+\varepsilon_{2}, & \Gamma=\mathrm{I}\left(\Gamma^{*}>0\right),
\end{array}
$$

$$
\text { Bargaining }^{*}=\mathrm{X}^{\prime} \beta_{\Gamma}+\alpha_{\mathrm{B}} \mathrm{EO}+\varepsilon_{3}, \quad \text { Bargaining }=\mathrm{I}\left(\text { Bargining }^{*}>0\right) \text {, }
$$

where $\Phi^{*}, \Gamma^{*}$ and Bargaining ${ }^{*}$ express the latent variables associated with product innovation, new production technology and bargaining, respectively, $\mathrm{I}(\cdot$ ) denotes the indicator function, $\mathrm{X}$ expresses a control vector, while EO expresses a dummy taking the value of 1 if the establishment is a member of an employer organisation. In addition, we assume that $\left(\varepsilon_{1}, \varepsilon_{2}, \varepsilon_{3}\right)$ are drawn from a standard trivariate Probit distribution, i.e.,

\footnotetext{
${ }^{6}$ As a rule of thumb, if $10 \%$ of the workers at a workplace (within a bargaining area) are unionised, the workers can demand a union agreement. Whether bargaining will be conducted locally, sector-wise or in combination, will be determined by the existing bargaining agreement made centrally between the employer organisations and worker unions).

${ }^{7}$ Although workers can trigger union bargaining rights through a statutory procedure introduced in the late 1990s it is rarely invoked.
} 
4) $\left(\varepsilon_{1}, \varepsilon_{2}, \varepsilon_{3}\right) \sim \mathrm{N}\left(\left[\begin{array}{l}0 \\ 0 \\ 0\end{array}\right],\left[\begin{array}{ccc}1 & \rho_{\Phi \Gamma} & \rho_{\Phi \mathrm{B}} \\ \rho_{\Gamma \Phi} & 1 & \rho_{\Gamma \mathrm{B}} \\ \rho_{\mathrm{B} \Phi} & \rho_{\mathrm{B} \Gamma} & 1\end{array}\right]\right)$.

Our empirical strategy has three components. First, we establish the empirical relationship between bargaining and employer membership of an employer organisation. Second, we assume that bargaining is exogenous and base our analysis on equations 1) and 2). Third, we assume that bargaining is endogenously determined, and base our analysis on equations 3) and 4). ${ }^{8}$

Since our data are based on stratified samples, we weight each observation in the regression by the inverse of the workplace's sampling probability (adjusted for non-response). This makes our empirical results representative at the national level for the population of workplaces with 5 or more employees (Britain)/10 employees (Norway). The models are identical for both countries.

\section{DATA}

Our data are the British Workplace Employment Relations Survey 2011 (WERS 2011) and the Norwegian Workplace Employment Relations Survey 2012 (NWERS 2012) supplemented by Norwegian register data. Although WERS (NWERS) covers workplaces with at least 5(10) employees in all sectors of the British (Norwegian) economy, we confine our analyses to the private sector. Information in WERS was acquired through face-to-face interviews which were conducted with the manager at the workplace responsible for employment relations. The response rate in 2011 was 46\%. Information in NWERS was acquired through computer-assisted telephone interviews which were conducted with the daily manager at the workplace or the manager responsible for employment relations. The response rate was $54 \%$, but since the main reason for non-response was respondents not being reached by Statistics Norway (36 percentage points) and

\footnotetext{
${ }^{8}$ If we estimate 3) without bargaining as a right-hand-side variable in the innovation equations (i.e., we no longer consider this as a recursive trivariate system, but still a trivariate Probit-system) and find that $\rho_{\Phi \mathrm{B}}$ and $\rho_{\Gamma \mathrm{B}}$ are equal to zero, our findings from equations 1) and 2) prevail. See also discussion in Fillipino et al. (2018).
} 
not by respondents refusing to participate, selection issues are unlikely to be a problem. ${ }^{9}$ WERS is documented in van Wanrooy et al. (2013), while NWERS is documented in Holmøy (2013).

\section{Innovation measures}

Our innovation measures for Britain are based on managerial responses to the following question: "Over the past two years has management here introduced any of the changes listed on this card? PROBE: Which others? UNTIL 'None'.:

1) Introduction of performance related pay

2) Introduction or upgrading of new technology (including computers)

3) Changes in working time arrangements

4) Changes in the organisation of work

5) Changes in work techniques or procedures

6) Introduction of initiatives to involve employees

7) Introduction of technologically new or significantly improved product or service

8) NONE None of these"

Our measure of labour-saving technological innovation is based on new production technology (a dummy taking the value of 1), which is defined directly from code 2). For product innovation we create a dummy for new or significantly improved products or services based on code 7).

The Norwegian innovation measures are very similar to the British measures. The measure for new or considerably improved products is based on two questions: "Over the last two years has the management introduced a new product?" and "Over the last two years has the management introduced considerable improvements of an already existing product?" Product innovation is then measured as a dummy taking the value of 1 if the manager response is yes to one of these questions, otherwise 0. Labour-saving technological innovation is based on the question: "Are the products

\footnotetext{
${ }^{9}$ In NWERS, only 12.7 percent of the issued sample refused to participate. In WERS, detectable response biases were corrected using sampling weights.
} 
or services provided by the workplace based on a different technology today compared to that of two years ago?" Technological innovation is then measured as a dummy taking the value of 1 if the manager response is yes to this question, otherwise 0 .

Finally, for both Britain and Norway, to acknowledge that our respondents might have misinterpreted the occurrence of product versus process innovation, we construct an innovation dummy taking the value of 1 if there is product or process innovation, zero otherwise.

\section{Bargaining and unionisation}

In both countries, our measure of union coverage is the presence at the workplace of one or more unions recognised by the employer for bargaining over pay and conditions of employment, whether the bargaining occurs at the workplace, organization or sectoral-level (1=union coverage, $0=$ not covered). These data are derived from the management questionnaire in WERS and in NWERS.

We also construct a measure expressing the prevalence of local wage bargaining, i.e., a dummy taking the value of 1 if local wage bargaining occurs at the workplace (irrespective of whether the workplace is also subject to sectoral or national level bargaining), 0 otherwise. This measure is constructed for Britain and Norway. As a robustness check, we will omit observations from Norway where union bargaining is only conducted at the sectoral or higher level. ${ }^{10}$

\section{Employer organisation}

In both countries, our measure of workplace membership in an employer organisation is directly taken from the management questionnaire in WERS and in NWERS $((1=$ workplace member of employer organisation, $0=$ not member).

\footnotetext{
${ }^{10}$ This case is omitted for Britain because it is very rare (1.5 percent of the workplaces and less than 20 workplaces in our sample). Although it is not the focus in our study, our descriptive statistics provide confirmation of the countrylevel differences in union density.
} 


\section{Control variables}

The previous literature as discussed by MFVR indicates that innovation is related to workplace age and size, market and skill structure. We control for these characteristics in steps.

Our basic control vector comprises a dummy for newly started business (less than two years in Norway and less than five years in Britain), and 11 industry dummies (roughly 1-digit SIC industry codes, but slightly more detailed). This vector captures variations in workers' outside options and workplaces' entry decisions, and comprises truly exogenous controls .

The full control vector then adds controls for the number of employees at the workplace (four dummy variables), product market conditions (two dummies taken the value of 1 for increased product demand and for reduced product demand (referenced no change), defined from questionnaire response on product demand development last two years), and workforce skills (the largest non-managerial occupational group (1-digit dummy). ${ }^{11}$

\section{UNION BARGAINING AND EMPLOYER ORGANISATION MEMBERSHIP}

Table 1 presents descriptive information on the incidence of our key union variables in Britain and Norway. We show workplace-weighted and employee-weighted estimates. The first row indicates that union agreements are six times more common among workplaces in Norway $(72 \%$ against $12 \%$ ). At the same time, we see that multi-employer agreements only are rare in Britain, while they are quite common in Norway. Thus, the difference in trade union agreements between Britain and Norway is driven by differences in the incidence of multi-employer only agreements. ${ }^{12}$

\footnotetext{
11 Admittedly size and occupational structure at a workplace could be considered endogenous, but these seem too important to ignore. One could also argue that we should incorporate controls for other variables such as wages and pay regimes. For example, incentive pay is important for innovation (Ederer and Manso, 2013; Curran and Walsworth, 2014). In our opinion, such variables are too endogenous to be incorporated so we have omitted them.

${ }^{12}$ In our data multi-employer agreements are virtually non-existent in British workplaces (1\% of workplaces and $<1 \%$ of employees) whereas they cover almost two-thirds $(63 \%)$ of workplaces and $71 \%$ of employees in Norway. The low incidence of multi-employer agreements means that for all practical purposes multi-employer agreements are ignorable in Britain. Thus, when we turn to the regression analyses, for Britain we only focus on a dummy for trade union agreements. In Norway, we conduct analyses discarding observations where no local bargaining occurs.
} 
In both countries, union agreements are more common in larger workplaces so the percentage of workers covered is higher than the percentage of workplaces. In Norway four-fifths of employees $(79 \%)$ are covered by a union agreement compared to just under one-third $(30 \%)$ in Britain. Nearly twice as many employees are employed in a local-agreement workplace in Norway is twice as large as compared with Britain (55\% against $25 \%)$. The percentage of employees in union membership (union density) is four times greater in Norway - 50\% against $12 \%$ for Britain. This is driven in part by the lower incidence of collective bargaining in Britain but also by lower density where there is an agreement.

The surveys therefore confirm that the two countries conform to the characterizations of them in the literature: Britain has low unionisation rates and fragmented collective bargaining akin to the U.S. - whereas Norway has very high levels of unionisation, which are based on centralized multi-employer bargaining arrangements typical of the Scandinavian case. However, a majority of union-covered workplaces in Norway are involved in local bargaining.

\section{[INSERT TABLE 1]}

We see in Table 1 that the two countries also differ when it comes to employer organisation membership. Seven-in-ten workplaces belong to an employer association in Norway, rising to over four-fifths when the workplace is unionised. In Britain, on the other hand, membership of an employer organisation is relatively unusual: only one-in-twenty workplaces belong to one, though the rate of membership is three times higher where the workplace is unionised.

In Table 2, we establish whether there is a link between employer organization membership and bargaining after taking into account market, industry and size differentials. For each country we estimate probit regressions for union bargaining, capturing the correlation with employer organization membership for three specifications: i) no controls (not shown), ii) market and size only, and iii) market, size, industry and skills. The figures in square brackets express the marginal effects of employer organization membership on union bargaining.

[INSERT TABLE 2] 
Both in Britain and in Norway workplace membership of an employer organisations is strongly positively associated with bargaining. For Britain, workplaces belonging to an employer organisation are 11-12 percentage points more likely to be involved in wage bargaining than nonemployer organisation workplaces. In Norway, employer organisation membership raises a workplace's probability of union wage bargaining by 18-26 percentage points. In the Norwegian case, when we discard workplaces involved in sectoral bargaining only (no local bargaining at all), the difference is 28 percentage points. Employer organisation membership is strongly associated with local bargaining in both Britain and Norway.

\section{UNIONISATION AND INNOVATION}

Table 3 shows the incidence of our innovation measures and their relationship with unionisation. Britain has more process innovation than Norway but less product innovation. The rate of product-only innovation is almost twice as high in Norway as it is in Britain (nearly $60 \%$ against $33 \%$ ), while technological process innovation only is one-and-a-half times more common in Britain than Norway (48\% against $30 \%) .^{13}$

\section{[INSERT TABLE 3]}

These differences in product and process innovation are not accounted for by differences in the underlying industrial structures in the two countries. ${ }^{14}$

Table 3 also reveals, both in Britain and Norway and regardless of type of innovation that workplaces are more likely to engage in innovation when unionized. For example, in Britain, union workplaces are more likely to engage in product-only innovation than non-union workplaces $(47 \%$

\footnotetext{
${ }^{13}$ Both the British and Norwegian product innovation figures are higher than the OECD-figures. While the text in the questionnaires that yield this information is similar, WERS and NWERS sample workplaces, while even smaller firms are sampled in the studies that yield the OECD-statistics. It is therefore likely that the lower OECD figures reflect, at least in part, small firms. Furthermore, NWERS provides a stratified sample taking into account time of entry, and the innovation activities might differ across the lifecycle of a workplace (or firm).

${ }^{14}$ To investigate the role played by industrial structure we produced counterfactuals for the incidence of innovation for each country by weighting their data using the industry composition taken from the other country. In a sense, we are making Norway observationally equivalent to Britain based on its industrial structure, and vice versa. It was apparent that differences in industrial structure - at least at this two-digit level - account for only a relatively small part of the observed differences in innovation rates across the two countries. These analyses are available on request.
} 
relative to $32 \%$ if non-union). This union/non-union difference is smaller in Norway (61\% against $56 \%$ ) but becomes larger when excluding those workplaces involved in multi-employer sectoral bargaining only (which is nearly non-existent in Britain). In Britain, union workplaces are also more likely to engage in technical process innovation than non-union workplaces $(55 \% \mathrm{v} 48 \%)$. The picture is similar but weaker in Norway: the union/non-union differentials are less pronounced. Finally, we see that for both countries but particularly so in Britain, it appears that the occurrence of both types of innovations are occurring more often under union bargaining (in Britain 37\% vs 24\%). Based on these simple unconditional descriptive statistics, it appears union status matters more for product and process innovation in Britain than it does in Norway, but the key finding is that in both countries, product and technological process innovations are more likely to occur in a bargaining environment. Of course, these unconditional correlations might be very misleading. For instance, the incidence of unionisation and innovation are likely to be linked to workplace size and industry, and this size effect may drive the union-innovation association.

Thus, we turn to the results from the multivariate regressions. In Table 4, we estimate bivariate Probit-regressions to see how union bargaining arrangements relate to product or technological innovation, contingent on taking bargaining as exogenously determined. Our control vector takes into account size and industry differences, as well as market characteristics and workforce occupational composition (in the form of shares). Then, in Table 5, we repeat the analysis of Table 4, but we now treat bargaining as a potentially endogenous variable and thus estimate recursive trivariate Probit-regressions. ${ }^{15}$

[INSERT TABLE 4]

[INSERT TABLE 5]

\footnotetext{
15 While the parameter associated with employer organization is strongly significant in the local bargaining equation for both Britain and Norway, one does not have a measure of instrument strength in such non-linear system estimation. However, if we ignore the fact that these innovations are part of the same process, and just analyse this as separate sets of linear probability regressions, then the employer organization instrument yields a Kleibergen-Paap Fvalue of over 37 for Norway, but only 4-5 for Britain. Thus, our instrument in the British case is clearly weaker than what we would have liked.
} 
Our primary interest is not the parameter estimates presented in Tables 4 and 5 , but on the predicted marginal effects associated with bargaining arising from these models (which we present in Table 6). However, we note that local bargaining in Table 4 appears to be strongly positive and significantly associated with the probability of introducing new products in both Britain and Norway. In Norway, we observe a sizeable significant impact of local bargaining on the probability of technological process innovation as well. Sectoral bargaining in Norway is not related to any innovation. We also note that the error terms in the product and process innovation equations are strongly correlated which we interpret as an indication that these innovations are jointly determined.

In Table 5 when we treat bargaining as endogenous and estimate a trivariate recursive Probit, we see that both the parameter estimates and their standard errors become significantly larger such that our estimates are less precise. ${ }^{16}$ For both Britain and Norway, the parameters associated with bargaining indicate a strongly positive impact on the probability of product innovation, and for Norway, this is strongly significant. Bargaining appears less important for technological process innovations in both countries. In both Britain and Norway, the error structure of the innovation equations indicates that these are strongly related, but neither in Britain nor in Norway are the errors in the bargaining equation significantly correlated with the errors from the innovation equations. ${ }^{17}$

Our key empirical findings are presented in Table 6. This table presents the average marginal effects of bargaining on the predicted probabilities of the four possible outcomes: i) both product and technological process innovation, ii) only technological process innovation, iii) only product innovation, and iv) no innovation of any kind. First, we see that when we treat bargaining

\footnotetext{
16 This is due to the strong relationship between bargaining and employer organisation membership in certain industries. We get qualitatively the same results, but more precise estimates, when applying a more parsimonious industry vector.

17 As pointed out by Fillipino et al. (2018), estimating a trivariate Probit-system without bargaining as a right-handvariable in the innovation equations yields strongly positively correlated errors between the innovation equations and the bargaining equation. Adding the recursive structure, then yields the opposite signs of the error structure.
} 
as exogenous, local bargaining increases the predicted probability of both product and technological process innovations by $8-10$ percentage points in both Britain and Norway compared to non-bargaining (the predicted probability for no-bargaining workplaces is roughly 22 percentage points). This is a strong impact. In Britain, product innovation only is also more likely among bargaining workplaces. In both countries, local bargaining workplaces are less likely to face no innovations than non-bargaining workplaces.

Second, when we treat bargaining as endogenous, in Britain the impact of local bargaining on the probability of both product and technological process innovation becomes weaker, but is still significant at a 1-percent level, and reveals that bargaining workplaces have two percentage points higher probability than non-bargaining workplaces. In Norway, with one exception, the average marginal effects are significant at 1 -percent level. We see that the average marginal impact of local bargaining on the probability of both product and technological process innovation is qualitatively unchanged (10 percentage points), but the impact of local bargaining on the probability of product innovation only increases strongly, indicating that local-bargaining workplaces have 15 percentage points higher probability of product innovation than their nonunion counterparts. The key empirical finding is that local bargaining makes the probability of both product and technological process innovation higher, as well as increasing the probability of product innovation only. Finally, note that when both innovations occur, this might entail a loss of workers to the plant and thus the union, but this utility loss for the union is offset by increased demand and wages following product innovations.

\section{CONCLUSION AND DISCUSSION}

To our knowledge, this is the first empirical workplace comparative analysis of the links between union bargaining and innovation. We compare union links to innovation in Britain and Norway, two very different countries in terms of union arrangements. Britain is akin to the U.S. with low levels of unionisation and, where union bargaining exists, it takes the form of local union 
agreements. In Norway, on the other hand, although multi-employer agreements dominate, a majority of the unionised workplaces also face local bargaining. The distinction we make between product and technological process innovations proves informative. Indeed, failure to disaggregate between types of innovation would have produced misleading results. Theoretically, we show that unions prefer product innovation to potentially labour-reducing technological process innovation, and that the former kind of innovation might offset the detrimental impact of the latter on union utility. Thus, when we address these issues empirically, our expectations are clear. Furthermore, our efforts to distinguish between aspects of unionisation within country prove informative since we find results differ somewhat according to whether the union agreement is at local or multiemployer level, i.e., sectoral bargaining is of no importance for innovations in Norway and its occurrence is negligible in Britain. That said, there are stark differences in innovation rates and the links between innovation and union status of workplaces across our two countries, which seem to relate to the broad characterisations of the two union systems in the literature.

Empirically we find strong support for the notion that local bargaining is related to more innovations - product and technical process innovations together, or just product innovations only. This is seen in the simple descriptive Table 3, and is confirmed in the multivariate analysis, with key results summarised in Table 6 . The picture described by the descriptive table holds when taking into account industry-, size-, market- and skill-differences across workplaces. In most cases, our estimates of the marginal effects are significant at a 1-percent level and imply economically important differences. The magnitude of the impact is slightly sensitive to whether one treats bargaining as an exogenous or endogenous variable in the innovation processes, but results appear economically significant regardless of treatment. When treated as exogenous, the estimated average marginal effects are quite comparable in Britain and Norway: local bargaining workplaces are roughly 8 percentage points more likely to conduct both product and process innovations than non-bargaining workplaces (which have a baseline probability of 22 percent). 
Thus, our results are as expected, and as indicated by the theoretical model, that unions prefer product innovation to labour-saving technological innovations. When both occur, this might entail a loss of workers to the plant and the union, but this utility loss for the union is offset by increased demand and wages following product innovations.

These empirical findings challenge the notion that local union bargaining is detrimental to innovation. However, many of the existing studies finding this were conducted some time ago: recent empirical studies of union effects on productivity indicate that unions are not detrimental to productivity. First, the empirical literature on unions and productivity suggests that relative productivity in the union sector has risen over time. For example, Blanchflower and Bryson (2009) show that the negative association between unionisation and productivity observed in the 1980s in Britain had disappeared by the 1990s. Second, Barth et al. (2020) show on Norwegian data that increasing union density is causally related to higher productivity and higher wages, but productivity more so. If productivity and innovations are related, our results are thus in line with these latter studies. Future research will reveal if our findings pertain to other innovations measures and will be robust over time.

\section{References}

Addison, J. T. and B.T. Hirsch (1989), "Union Effects on productivity, profits and growth: Has the Long-run Arrived?” Journal of Labor Economics, 7, 72 - 105.

Addison, J. T., P. Teixeira, K. Evers, and L. Bellman (2017), "Collective bargaining and innovation in Germany: Cooperative Industrial Relations?”. Industrial Relations, 56, 73 - 121.

Addison, J., C. Schnabel, and J. Wagner (2001), "Work Councils in Germany: Their Effect on Establishment Performance," Oxford Economic Papers, 53, 659 - 694.

Agell, J. (1999), “On the benefits from rigid labour markets: norms, market failures, and social insurance," Economic Journal, 109, F143 - 64. 
Aghion, P., and P. Howitt (1992), 'A Model of Growth through Creative Destruction', Econometrica, $60,323-51$

Aghion, P and P. Howitt (2007), "Capital, Innovation, and Growth Accounting" Oxford Review of Economic Policy, 23, 79-93

Acharya, V., R. P. Baghai, and K.V. Subramanian (2014). "Wrongful Discharge Laws and Innovation", Review of Financial Studies, 2 (1), 301-34.

Appelbaum, E., Bailey, T., Berg, P. and Kalleberg, A.L. (2000) Manufacturing advantage: Why highperformance work systems pay off, Ithaca NY: Cornell University Press.

Askenazy, P. and E. Caroli. 2010. "Innovative Work Practices, Information technologies, and Working Conditions: Evidence for France.” Industrial Relations, 49(4), pp. 544 - 565.

Barth, E. K. M. Moene and F. Willumsen (2014), “The Scandinavian Model - an interpretation,” Journal of Public Economics, 117, 60 -72).

Barth, E. A. Bryson and H. Dale-Olsen (2020), “Union density effects on productivity and wages". Economic Journal (https://doi.org/10.1093/ej/ueaa048).

Basak, D. (2012), Price competition and the effects of wage bargaining on process innovation, Manuscript. University of Nottingham.

Basak, D. and A. Mukherjee (2018), “Labour unionisation structure and product innovation”, International Review of Economics and Finance, 55: 98-110.

Beladi, H. and A. Mukherjee (2017), "Union Bargaining Power, Subcontracting and Innovation," Journal of Economic Behaviour \& Organization, 137, 90 - 104.

Bernard, A., S. Redding and P. Schott (2010), "Multiple-Product Firms and Product Switching," American Economic Review, 100, 70 - 97.

Black, S. E. and L. M. Lynch (2001),'How To Compete: The Impact Of Workplace Practices And Information Technology On Productivity," Review of Economics and Statistics, 83, 434-445.

Black, S. E. and L. M. Lynch. 2004. 'What's driving the new economy?: the benefits of workplace innovations." The Economic Journal, 114, pp. F97 -F116. 
Blanchflower, D. G. and Bryson, A. (2009) 'Trade union decline and the economics of the workplace', Chapter 3 in W. Brown, A. Bryson, J. Forth and K. Whitfield (eds.) The Evolution of the Modern Workplace, pp. 48-73, Cambridge University Press

Bloom, N. and Van Reenen, J. 2007. "Measuring and Explaining Management Practices Across Firms and Countries.” The Quarterly Journal of Economics, CXXII, pp. 1351-1408

Bloom, N., M. Schankerman and J. Van Reenen (2013), "Identifying technology spillovers and product market rivalry," Econometrica, 81, 1347 - 1393.

Bonanno, G. and B. Haworth (1998), "Intensity of Competition and the Choice between Product and Process Innovation," International Journal of Industrial Organization, 16, 495 -510.

Bordia, P., Hunt, E., Paulsen, N., Tourish, D., DiFonzo, N. (2004). "Uncertainty during organizational change: is it all about control?” European Journal of Work and Organizational Psychology, 13, 345-365

Bradley, D. J., Kim, I. and Tian, X. (2016) “Do Unions Affect Innovation?”, Management Science, 63, 7: $2251-2271$

Braun, S. (2011), "Unionisation structures, productivity and firm performance: New insights from a heterogeneous firm model," Labour Economics, 18, 120 - 129.

Broda, C. and D. E. Weinstein (2010), "Product Creation and Destruction: Evidence and Price Implication," American Economic Review, 100, 691 - 723.

Bryson, A., Barth, E. and Dale-Olsen, H. (2013) 'The Effects of Organizational Change on Worker Wellbeing and the Moderating Role of Trade Unions', Industrial and Labor Relations Review, 66, 4: 989-1011

Bryson, A. and Forth, J. (2016), "The UK Productivity Puzzle". in Askenazy, P., Bellmann, L., Bryson, A. and Moreno-Galbis, E. (eds.) The Productivity Purzle across Europe, Oxford University Press, pp. 129-173

Bryson, A., Charlwood, A. and Forth, J. (2006) 'Worker Voice, Managerial Response and Labour Productivity: An Empirical Investigation', Industrial Relations Journal, 37: 5, 438-455 
Bryson, A., Forth, J. and Kirby, S. 2005. "High-performance practices, trade union representation and workplace performance in Britain." Scottish Journal of Political Economy, 53, 3, pp. 451 491

Calmfors, L. and J. Driffill (1988), "Bargaining structure, corporatism and macroeconomic performance," Economic Policy 3, 13-61.

Cardullo, G., M. Conti and G. Sulis (2020), “A model of unions, two-tier bargaining and capital investment," Labour Economics, 67 (101936)

Caroli, E. and J. Van Reenen (2001). "Skill-biased Organizational Change? Evidence from a Panel of British and French Establishments.” The Quarterly Journal of Economics, 116, pp. 1449 1492.

Cohen, W. M. and S. Klepper (1996), "Firm Size and the Nature of Innovation wthin Inustries: The Case of Process and Product R\&D," Review of Economics and Statistics, 78, 232 - 243.

Cummins, J., and G. Violante (2002), 'Investment Specific Technical Change in the US (19472000): Measurement and Macroeconomic Consequences', Review of Economic Dynamics, 5, $243-84$.

Curran, B. and S. Walsworth (2014), "Can you pay employees to innovate? Evidence from the Canadian private sector," Human Resource Management Journal, 24, 290 - 306.

Doucouluagos, C. and P. Laroche (2003), "What Do Unions Do To Productivity? A MetaAnalysis," Industrial Relation, 42, 650 -691.

Doucouliagos, C. and P. Laroche (2013), "Unions and Innovation: New Insights From the CrossCountry Evidence,” Industrial Relations, 52, 467 - 491.

Ederer, F. and G. Manso (2013), “Is Pay-for-Performance Detrimental to Innovation,” Management Science, 59, 1496 - 1513.

Faggio, G., K. G. Salvanes and J. Van Reenen (2010), “The evolution of inequality in productivity and wages: panel data evidence“, Industrial and Corporate Change, 19, 1919 - 1951. 
Fillipino, M., W. H. Greene, N. Kumar, L. L. Martinez-Cruz (2018), “A note on the different interpretation of the correlation parameters in the Bivariate Probit and the Recursive Bivariate Probit," Economics Letters, 167, 104- 107.

Flach, L. and M. Irlacher (2018), "Product versus Process: Innovation Strategies of Multi-Product Firms". American Economic Journal: Microeconomics, 10, 236 - 277.

Freeman, R. and J. Medoff (1984), What do Unions do? New York: Basic Books.

Frost, A. C. 2001. "Reconceptualizing local union responses to workplace restructuring in North America." British Journal of Industrial Relations, 39, pp. 539 - 564

Goodridge, P., Haskel, J. and Wallis, G. (2013) "Can intangible investment explain the UK Productivity Puzzle?", National Institute Economic Review, 224: R48-R58

Griffith, R., S. Redding, and J. Van Reenen (2004), "Mapping the two faces of R\&D: Productivity growth in a panel of OECD industries," Review of Economic Studies, 86, 883 - 895.

Grossmann, G. M and E. Helpman (1991), Innovation and Growth in the Global Economy. Cambridge, MA.: MIT Press.

Grout, P. A. (1984), "Investment and Wages in the Absence of Binding Contracts: A Nash Bargaining Approach,” Econometrica, 52, 449 - 460.

Hall, B. (2011), Innovation and productivity. NBER Working paper 17178.

Haucap, J. and C. Wey (2004), "Unionisation structures and innovation incentives," Economic Journal, 114, C149 - C165.

Hirsch, B. (1992), "Firm Investment Behaviour and Collective Bargaining Strategy," Industrial Relations, 31, $95-121$.

Holmøy, A. (2013), Arbeids- og bedriftsundersokelsen 2012. Dokumentasjonsrapport. Notater 38/2013. Oslo og Kongsvinger: Statistisk sentralbyrå.

Ichniowski, C., Shaw, K. and Prennushi, G. 1997. “The Effects of Human Resource Management Practices on Productivity: A Study of Steel Finishing Lines." American Economic Review, 87, pp. 291-313 
Jimeno and Thomas (2013), "Collective bargaining, firm heterogeneity, and unemployment", European Economic Review, 59 (DOI: 10.2139/ssrn.1968359)

Johnsen, G. E. (1990), “Work Rules, Featherbedding and Pareto-Optimal Union-Management Bargaining," Journal of Labor Economics, 8, S237 -S259.

Junge, M., B. Servergnini and A. Sørensen (2012), Product-Marketing Innovation, Skills, and Firm Productivity Growth. Copenhagen Business School Working paper 1-2012.

Khandelwal, A. (2010), “The Long and Short (of) Quality Ladders," Review of Economic Studies, 77, $1450-1476$.

Lévesque, C. and Murray, G. 2005. "Union involvement in workplace change: A comparative study of local unions in Canada and Mexico.” British journal of Industrial Relations, 43, pp. 489 514.

Lin, P. and K. Saggi (2002), "Product differentiation, process R\&D, and the nature of market competition,” European Economic Review, 46, 201 - 211.

Lommerud, K. E. and O. R. Straume (2012), “Employment protection versus flexicurity: On technology adoption in unionised firms," Scandinavian Journal of Economics, 114, 177 - 199.

López, M . C. and R. A. Naylor (2004), “The Cournot-Bertrand profit differential: A reversal result in a differentiated duopoly with wage bargaining," European Economic Review, 48, 681 - 96.

Malcomson, J. (1983), “Trade unions and economic efficiency.” The Economic Journal, 93, pp. 5065

Malcomson, J. (1997), “Contracts, hold-up, and labour markets," Journal of Economic Literature, 35, $1916-57$.

Manning, A. (1987a), “An integration of trade union models in a sequential bargaining framework," Economic Journal, 97, 121 - 139.

Manning, A. (1987b), "Collective bargaining institutions and efficiency," European Economic Review, $31,168-176$. 
Melitz, M. J. and G. I. P. Ottaviano (2008), "Market Size, Trade, and Productivity," Review of Economic Studies, 75, 295 - 316.

Menezes-Filho, N.(1997), "Unions and profitability over the 1980s: Some Evidence on UnionFirm Bargaining in the UK," Economic Journal, 107, 651 - 670.

Menezes-Filho, N. and Van Reenen, J. (2003). "Unions and Innovation: A Survey of the Theory and Empirical Evidence", In Addison, J. and C. Schnabel (eds.), International Handbook of Trade Unions. Edward Elgar, 293 - 334.

Metcalf, D. (2003), "Unions and Productivity, Financial Performance and Investments," In Addison, J. and C. Schnabel (eds.), International Handbook of Trade Unions. Edward Elgar.

Metcalf, D. (1990), "Union presence and labour productivity in British Manufacturing Industry.A reply to Nolan and Margison.” British Journal of Industrial Relations, 28, 249 - 266.

Moene, K. and M. Wallerstein (1997), "Pay Inequality," Journal of Labor Economics, 15, 403 - 430.

Mukherhjee, A. and E. Pennings (2011), "Unionisation structure, licencing and innovation," International Journal of Industrial Organisation, 29, 232 - 241.

Nickell, S. (2001), "Final Remarks," In Boeri, T., Brugiavini and L. Calmfors (eds.), The Role of Unions in the Twenty-First Century. Oxford: Oxford University Press.

OECD (2003), The Source of Economic Growth in OECD Countries. Paris: OECD.

OECD (2007), OECD Economic Surveys: Norway. Paris: OECD.

OECD (2017), «Ch.4 Collective bargaining in a changing world of work”, Employment Outlook 2017, $125-186$.

OECD (2018), «Ch.3 The Role of Collective Bargaining Systems for Good Labour Market Performance”, Employment Outlook 2017, 73 - 122.

Oswald, A. J. (1985), "The economic theory of trade unions: an introductory survey," Scandinavian Journal of Economics, 87, 160 - 193.

de Pinto, M. (2019). "The impact of unionization structures with heterogeneous firms and rentsharing motives", The Scandinavian Journal of Economics, 121(1): 298-325. 
Romer P.M. (1990), “Endogenous Technical Change,” Journal of Political Economy, 98, 71-102.

Scherer, F. M. and D. Ross (1990), Industrial Market Structure and Economics of Performance. Boston, MA: Houghton Mifflin.

Ulph, A. and D. Ulph (1994), "Labour markets and innovation: ex-post bargaining," European Economic Review, 38, 195 - 210.

Ulph, A. and D. Ulph (1998), "Labour markets, bargaining and innovation," European Economic Review, 42, 931 - 939.

Ulph, A. and D. Ulph (2001), "Strategic innovation with complete and incomplete labour market contracts," Scandinavian Journal of Economics, 103, 265 - 282.

Vernon, G. and M. Rogers (2013), "Where Do Unions Add Value? Predominant Organizing Principle, Union Strength and Manufacturing Productivity Growth in the OECD," British Journal of Industrial Relations, 51, 1 - 27.

Wallerstein, M. (1999), "Wage-setting institutions and pay inequality in advanced industrial societies", American Journal of Political Science, 43, 649-680.

WEF (2013), The Global Competitiveness Report 2013-2014: The Full Data Edition. Geneve: World Economic Forum.

Zheng, X. and S. Rabe-Hesketh (2007), "Estimating parameters of dichotous and ordinal item reponse models with gllamm," Stata Journal, 7, 313 - 333.

van Wanrooy, B., H. Bewley, A. Bryson, J. Forth, S. Freeth, L. Stokes and S. Wood (2013), Employment Relations in the Shadow of Recession. Findings from the 2011 Workplace Employment Relations Study. London: Palgrave Macmillan. 


\section{Theoretical appendix}

The model set-up is as follows: consider a product market monopolist firm existing for two periods, where wages are set by a monopoly union each period, with employment levels set by the firm given union-set wages. Let product demand be given by a standard linear inverse product demand function $\mathrm{p}=\mathrm{A}-\mathrm{q}$, where $\mathrm{A}$ denotes a parameter expressing the price when nobody demands the product, q denotes the production quantity of the firm, which is equal to the firm's labour demand, $q=1$. The firm sets employment to maximise profits, while the union set wages to maximise a Stone-Geary utility function, $\mathrm{U}=\left(\mathrm{w}-\mathrm{w}_{0}\right)^{\theta} \mathrm{l}, \theta \geq 0$, where $\mathrm{w}$ and $\mathrm{w}_{0}$ denote wage and reservation wage (opportunity cost of labour), respectively, 1 denotes employment, and $\theta$ denotes a parameter expressing the union's preference for wages versus employment. When $\theta=0$, only employment matters for the union, and the competitive wage arises. We also assume that $2 \mathrm{w}_{0} \leq \mathrm{A}$.

Since it is costless for the firm to adjust employment in the second period, for our purpose we can ignore period 1 and thus focus on the impact of labour-saving technological innovations and/or product innovations in period 2 (and also ignore any subscript referring to the time period).

\section{A) Reference (no innovation)}

Let product demand be given by a standard linear inverse product demand function $\mathrm{p}=\mathrm{A}-\mathrm{q}$, while the production quantity of the firm is related to the firm's labour demand, $q=1$. Then we can derive the following simple relationships:

Firm employment rule: $\max _{1}\{\Pi=\mathrm{pq}-\mathrm{wl}\} \rightarrow \frac{\partial}{\partial l}((A-l) l-w l)=0 \rightarrow 1=(\mathrm{A}-\mathrm{w}) / 2$.

Union wages: $\max _{\mathrm{w}}\left\{\mathrm{U}=\left(\mathrm{w}-\mathrm{w}_{0}\right)^{\theta} \mathrm{l}\right\} \rightarrow \frac{\partial}{\partial w}\left(\left(\mathrm{w}-w_{0}\right)^{\theta}(\mathrm{A}-\mathrm{w}) / 2\right)=0 \rightarrow \mathrm{w}^{*}=\left(\theta \mathrm{A}+\mathrm{w}_{0}\right) /(1+\theta)$.

Firm employment: $1^{*}=\left(\mathrm{A}-\left[\left(\theta \mathrm{A}+\mathrm{w}_{0}\right) /(1+\theta)\right]\right) / 2=\left(\mathrm{A}-\mathrm{w}_{0}\right) /[2(1+\theta)]$.

Firm profits: $\Pi^{*}=\left(\mathrm{A}-\frac{A-w_{0}}{2(\theta+1)}\right)\left(\frac{A-w_{0}}{2(\theta+1)}\right)-\frac{\theta A+w_{0}}{(\theta+1)}\left(\frac{A-w_{0}}{2(\theta+1)}\right)=\left(\frac{A-w_{0}}{2(\theta+1)}\right)^{2}$.

Union utility: $\mathrm{U}^{*}=\frac{\theta^{\theta}}{2}\left(\frac{A-w_{0}}{(\theta+1)}\right)^{\theta+1}$ 
We see that as the union preference for employment increases $(\theta \rightarrow 0)$, wages drop, employment and firm profits increase.

\section{B) Labour-saving technology}

Product demand is then equal to the reference case, $\mathrm{p}=\mathrm{A}-\mathrm{q}$, while the production quantity of the firm is related to the firm's labour demand incorporating labour-saving technology, $\mathrm{q}=\Gamma \mathrm{l}$, where $\Gamma>1$. Then we can derive the following simple relationships:

Firm employment rule: $\max _{1}\{\Pi=\mathrm{pq}-\mathrm{wl}\} \rightarrow \frac{\partial}{\partial l}((A-\Gamma l) \Gamma l-w l)=0 \rightarrow \mathrm{l}=(\Gamma A-\mathrm{w}) / 2 \Gamma^{2}$. Union wages: $\max _{\mathrm{w}}\left\{\mathrm{U}=\left(\mathrm{w}-\mathrm{w}_{0}\right)^{\theta} \mathrm{l}\right\} \rightarrow \frac{\partial}{\partial w}\left(\left(\mathrm{w}-w_{0}\right)^{\theta}(\Gamma \mathrm{A}-\mathrm{w}) / 2 \Gamma^{2}\right)=0 \rightarrow \mathrm{w}^{*} \Gamma=\left(\theta \Gamma A+\mathrm{w}_{0}\right) /(1+\theta)$. Firm employment: $1^{*}=\left(\mathrm{A}-\left[\left(\theta \Gamma \mathrm{A}+\mathrm{w}_{0}\right) /(1+\theta)\right]\right) / 2 \Gamma^{2}=\left(\Gamma \mathrm{A}-\mathrm{w}_{0}\right) /\left[2 \Gamma^{2}(1+\theta)\right]$.

Firm profits: $\Pi^{*} \Gamma=\left(\mathrm{A}-\Gamma \frac{\Gamma A-w_{0}}{2(\theta+1) \Gamma^{2}}\right) \Gamma\left(\frac{\Gamma A-w_{0}}{2(\theta+1) \Gamma^{2}}\right)-\frac{\theta \Gamma A+w_{0}}{(\theta+1)}\left(\frac{\Gamma A-w_{0}}{2(\theta+1) \Gamma^{2}}\right)=\left(\frac{\Gamma A-w_{0}}{2(\theta+1) \Gamma}\right)^{2}$. Union utility: $\mathrm{U}^{*} \Gamma=\frac{\theta^{\theta}}{2 \Gamma^{2}}\left(\frac{\Gamma A-w_{0}}{(\theta+1)}\right)^{\theta+1}$

First, we see that labour-saving technology increases union wages. Second, we see that higher $\Gamma$ yields lower employment. Third, firms always profit from labour-saving technologies (ignoring implementation costs). Higher employment preferences (lower values of $\theta$ less than 1 ) might cause unions to experience a utility loss from labour-saving technologies, but this depends on the employment preferences (the size of $\theta$ ), how significant the innovation is (the size of $\Gamma$ ), and the relationship between $\mathrm{A}$ and $\mathrm{w}_{0} .{ }^{18}$ Thus, unions might not endorse labour-saving technologies, and might actively increase the implementation costs associated with these.

\section{C) Product innovation}

Product demand is then expressed by the demand function, $\mathrm{p}=\Phi \mathrm{A}-\mathrm{q}$, where product innovation is modelled by $\Phi>1$, while the production quantity of the firm is related to the firm's labour demand, $\mathrm{q}=\mathrm{l}$. Then we can derive the following simple relationships:

\footnotetext{
${ }^{18}$ For example, if $\mathrm{A}=2 \mathrm{w}_{0}$, a union with $\theta=0.1$ prefer no innovation to a minor innovation like $\Gamma=11 / 10$ or to a more significant innovation of $\Gamma=5 / 4$. If $A$ increases to $A=10 \mathrm{w}_{0}$, even a union with $\theta=0.8$ prefers no innovation to these previous innovations.
} 
Firm employment rule: $\max _{1}\{\Pi=\mathrm{pq}-\mathrm{wl}\} \rightarrow \frac{\partial}{\partial l}((\Phi A-l) l-w l)=0 \rightarrow l=(\Phi A-\mathrm{w}) / 2$.

Union wages: $\max _{\mathrm{w}}\left\{\mathrm{U}=\left(\mathrm{w}-\mathrm{w}_{0}\right)^{\theta} \mathrm{I}\right\} \rightarrow \frac{\partial}{\partial w}\left(\left(\mathrm{w}-w_{0}\right)^{\theta}(\Phi \mathrm{A}-\mathrm{w}) / 2\right)=0 \rightarrow \mathrm{w}^{*} \Phi=\left(\theta \Phi \mathrm{A}+\mathrm{w}_{0}\right) /(1+\theta)$.

Firm employment: $1^{* \Phi}=\left(\Phi A-\left[\left(\theta \Phi A+\mathrm{w}_{0}\right) /(1+\theta)\right]\right) / 2=\left(\Phi A-\mathrm{w}_{0}\right) /[2(1+\theta)]$.

Firm profits: $\Pi^{* \Phi}=\left(\Phi A-\frac{\Phi A-w_{0}}{2(\theta+1)}\right)\left(\frac{\Phi A-w_{0}}{2(\theta+1)}\right)-\frac{\theta \Phi A+w_{0}}{(\theta+1)}\left(\frac{\Phi A-w_{0}}{2(\theta+1)}\right)=\left(\frac{\Phi A-w_{0}}{2(\theta+1)}\right)^{2}$.

Union utility: $\mathrm{U}^{* \Phi}=\frac{\theta^{\theta}}{2}\left(\frac{\Phi A-w_{0}}{(\theta+1)}\right)^{\theta+1}$

First, we see that product innovation increases union wages. In contrast to labour-saving innovations, we see that higher $\Phi$ yields increased employment. Third, firms always profit from product innovation (ignoring implementation costs). Finally, as $\Phi$ increases, regardless of employment preferences, unions experience a utility gain from product innovations.

\section{D) Product and labour-saving innovations}

Product demand is expressed as in $\mathrm{C}$ ) by the demand function, $\mathrm{p}=\Phi \mathrm{A}-\mathrm{q}$, where product innovation is modelled by $\Phi>1$, while the production quantity of the firm is related to the firm's labour demand incorporating the labour-saving technology, $q=\Gamma$, where $\Gamma>1$. Then we can derive the following simple relationships:

Firm employment rule: $\max _{1}\{\Pi=\mathrm{pq}-\mathrm{wl}\} \rightarrow \frac{\partial}{\partial l}((\Phi A-\Gamma l) \Gamma l-w l)=0 \rightarrow 1=(\Phi \Gamma A-\mathrm{w}) / 2 \Gamma^{2}$.

Union wages: $\max _{\mathrm{w}}\left\{\mathrm{U}=\left(\mathrm{w}-\mathrm{w}_{0}\right)^{\theta} \mathrm{l}\right\} \rightarrow \frac{\partial}{\partial w}\left(\left(\mathrm{w}-w_{0}\right)^{\theta}(\Phi \Gamma \mathrm{A}-\mathrm{w}) / 2 \Gamma^{2}\right)=0 \rightarrow$ $\mathrm{w}^{*}{ }^{\oplus \Gamma}=\left(\theta \Phi \Gamma A+\mathrm{w}_{0}\right) /(1+\theta)$.

Firm employment: $1^{* \Phi \Gamma}=\left(\Phi A-\left[\left(\theta \Phi A+\mathrm{w}_{0}\right) /(1+\theta)\right]\right) / 2=\left(\Phi \Gamma A-\mathrm{w}_{0}\right) /\left[2(1+\theta) \Gamma^{2}\right]$.

Firm profits: $\Pi^{* \Phi \Gamma}=\left(\Phi A-\Gamma \frac{\Phi \Gamma A-w_{0}}{2(\theta+1) \Gamma^{2}}\right) \Gamma\left(\frac{\Phi \Gamma A-w_{0}}{2(\theta+1) \Gamma^{2}}\right)-\frac{\theta \Phi \Gamma A+w_{0}}{(\theta+1)}\left(\frac{\Phi \Gamma A-w_{0}}{2(\theta+1) \Gamma^{2}}\right)=\left(\frac{\Phi \Gamma A-w_{0}}{2(\theta+1) \Gamma}\right)^{2}$. Union utility: $\mathrm{U}^{* \Phi \Gamma}=\frac{\theta^{\theta}}{2 \Gamma^{2}}\left(\frac{\Phi \Gamma A-w_{0}}{(\theta+1)}\right)^{\theta+1}$

As in the two previous innovation cases, union wages and firm profits increase. However, in contrast to the case of labour-saving innovations only, we see that increased employment might follow from these two innovations jointly, if they are of equal size. Similarly, depending on the size 
of the innovations and regardless of employment preferences, unions might experience a utility gain from both innovations. Thus, although unions might not endorse labour-saving technologies alone, they might accept these if they are combined with product innovations.

E) The Competitive Case

In the competitive case, no union exists and the wage is always equal to the reservation wage, $\mathrm{w}=\mathrm{w}_{0}$. The firm chose employment to maximize profits. We get similar expressions as in A)-D), but with $\theta=0$. For example, firm profit in the reference case (no innovation) is $\Pi^{*}=\left(\frac{A-w_{0}}{2}\right)^{2}$. Similarly, if both labour-saving and product innovations occur, profit is $\Pi^{* \Phi \Gamma}=\left(\frac{\Phi \Gamma A-w_{0}}{2 \Gamma}\right)^{2}$. Thus wages are lower in the competitive case than in the union case, while employment and firm profits are similarly higher. Ignoring the implementation costs, firms always benefits from innovations.

\section{F) Implementation costs and innovation incentives}

Let $\Delta$ denote the difference between the innovation outcome and the reference case, and let subscript $j \in(\mathrm{c}, \mathrm{u})$ denote the $\mathrm{c}$ (ompetitive) or the $\mathrm{u}($ nion) case. For example, $\Delta \Pi_{\mathrm{c}}{ }^{*} \Gamma=\left(\frac{\Phi \Gamma A-w_{0}}{2 \Gamma}\right)^{2}-\left(\frac{A-w_{0}}{2}\right)^{2}$. Then we see that $\Delta \Pi_{\mathrm{u}}{ }^{{ }^{\mathrm{K}}}=\left(\frac{1}{(\theta+1)}\right)^{2} \Delta \Pi_{\mathrm{c}}{ }^{{ }_{\mathrm{K}}}$, where $\mathrm{K} \in(\Phi, \Gamma, \Phi \Gamma)$. Thus, when ignoring the implementation costs, the benefits from innovation are higher in the competitive case than under union bargaining, but that this difference diminishes as union preference for employment increases (i.e., $\theta \rightarrow 0$ ).

To close this simple model, introduce implementation costs, $\mathrm{I}=\mathrm{I}(\Phi, \Gamma, \Delta \mathrm{U})$. Note that the union's influence on the implementation costs is ambiguous. On one hand, as seen in C) reduced union utility from innovation might increase the innovation costs associated with labour-saving innovations. On the other hand, as seen in Bryson et al. (2013), unions can be conducive to the implementation of innovations. In the competitive case, with no union, $\Delta \mathrm{U}=0$. Thus, innovations will be conducted so that marginal profits from innovation(s) equals marginal costs of innovations, i.e., $\Delta \prod_{\mathrm{j}}^{{ }^{*} \mathrm{~K}}=\mathrm{I}(\Phi, \Gamma, \Delta \mathrm{U})$. 
TABLE 1

Collective Bargaining, Unionisation and Employer Organisation

\begin{tabular}{|c|c|c|c|c|}
\hline \multirow[b]{2}{*}{ Trade union agreement (TUA) } & \multicolumn{2}{|c|}{ BRITAIN } & \multicolumn{2}{|c|}{ NORWAY } \\
\hline & Workplaces & Workers & Workplaces & Workers \\
\hline Any TUA & 0.117 & 0.300 & 0.717 & 0.785 \\
\hline TUA involving local bargaining & 0.104 & 0.253 & 0.405 & 0.547 \\
\hline \multicolumn{5}{|l|}{ Union density } \\
\hline Union and non-union sectors & 0.041 & 0.123 & 0.400 & 0.498 \\
\hline Any TUA & 0.256 & 0.376 & 0.462 & 0.557 \\
\hline TUA involving local bargaining & 0.257 & 0.379 & 0.527 & 0.607 \\
\hline \multicolumn{5}{|l|}{ Employer organization } \\
\hline Union and non-union sectors & 0.054 & 0.133 & 0.719 & 0.800 \\
\hline Any TUA & 0.167 & 0.277 & 0.818 & 0.887 \\
\hline TUA involving local bargaining & 0.119 & 0.219 & 0.829 & 0.905 \\
\hline
\end{tabular}

Note: Private sector workplaces only. Source: Workplace and Employment Relations Survey 2011 (Britain) and Norwegian Workplace and Employment Relations Survey 2012. The columns headed by workers and workplaces express whether the figures are representative for the population of workers or the population of workplaces, respectively. 
TABLE 2

The Relationship between Union Bargaining and Employer Organisation Membership

\begin{tabular}{|c|c|c|c|c|c|}
\hline & \multicolumn{2}{|c|}{ Britain } & \multicolumn{3}{|c|}{ Norway } \\
\hline & & & & & Excludes sectoral \\
\hline & 1 & 2 & 3 & 4 & 5 \\
\hline \multirow[t]{3}{*}{ Employer organisation } & $0.707^{* *}$ & $0.365^{*}$ & $0.862^{* *}$ & $0.846^{* *}$ & $0.927^{* *}$ \\
\hline & $(0.262)$ & $(0.168)$ & $(0.129)$ & $(0.134)$ & $(0.152)$ \\
\hline & {$\left[0.118^{*}\right]$} & {$\left[0.120^{*}\right]$} & {$\left[0.246^{* *}\right]$} & {$\left[0.229^{* *}\right]$} & {$\left[0.282^{* *}\right]$} \\
\hline \multicolumn{6}{|l|}{ Controls } \\
\hline Basic & Yes & Yes & Yes & Yes & Yes \\
\hline Size, Market, Skills & & Yes & & Yes & Yes \\
\hline $\mathrm{N}$ & 1831 & 1831 & 1081 & 1081 & 808 \\
\hline
\end{tabular}

Note: Method: Probit. Dependent variable: dummy for bargaining. Private sector workplaces only. Source: Workplace and Employment Relations Survey 2011 (Britain) and Norwegian Workplace and Employment Relations Survey 2012. Each observation is weighted by the inverse of the sampling probability of the workplace adjusted for no-response. Control vectors: Basic: dummies for newly started business, and 10 industry dummies; Size, Market, Skills: size (4 categories), dummies for increased or reduced demand, exporter, main occupation dummies (9). Robust standard errors are reported in parentheses. Marginal effects are reported in squared brackets. ${ }^{x},{ }^{*}$ and ${ }^{* *}$ denote 10,5 and 1 percent level of significance, respectively. 
TABLE 3

Bargaining regimes and Innovations

\begin{tabular}{|c|c|c|c|c|c|c|c|}
\hline & & BRITAIN & & & & RWAY & \\
\hline & All & Not TUA & TUA & All & Not & TUA & TUA- local \\
\hline & & & & & TUA & & \\
\hline New product $(\mathrm{P})$ & 0.336 & 0.319 & 0.466 & 0.596 & 0.564 & 0.609 & 0.645 \\
\hline New tech.(T) & 0.483 & 0.477 & 0.548 & 0.308 & 0.283 & 0.317 & 0.352 \\
\hline New P AND new T & 0.250 & 0.235 & 0.369 & 0.258 & 0.248 & 0.258 & 0.293 \\
\hline
\end{tabular}

Note: Private sector workplaces only. TUA= trade union agreement. Source: Workplace and Employment Relations Survey 2011 (Britain) and Norwegian Workplace and Employment Relations Survey 2012. Each observation is weighted by the inverse of the sampling probability of the workplace adjusted for no-response. Thus the table reports figures representative across the distribution of workplaces. 
TABLE 4

Do bargaining influence product or technological process innovation equally?

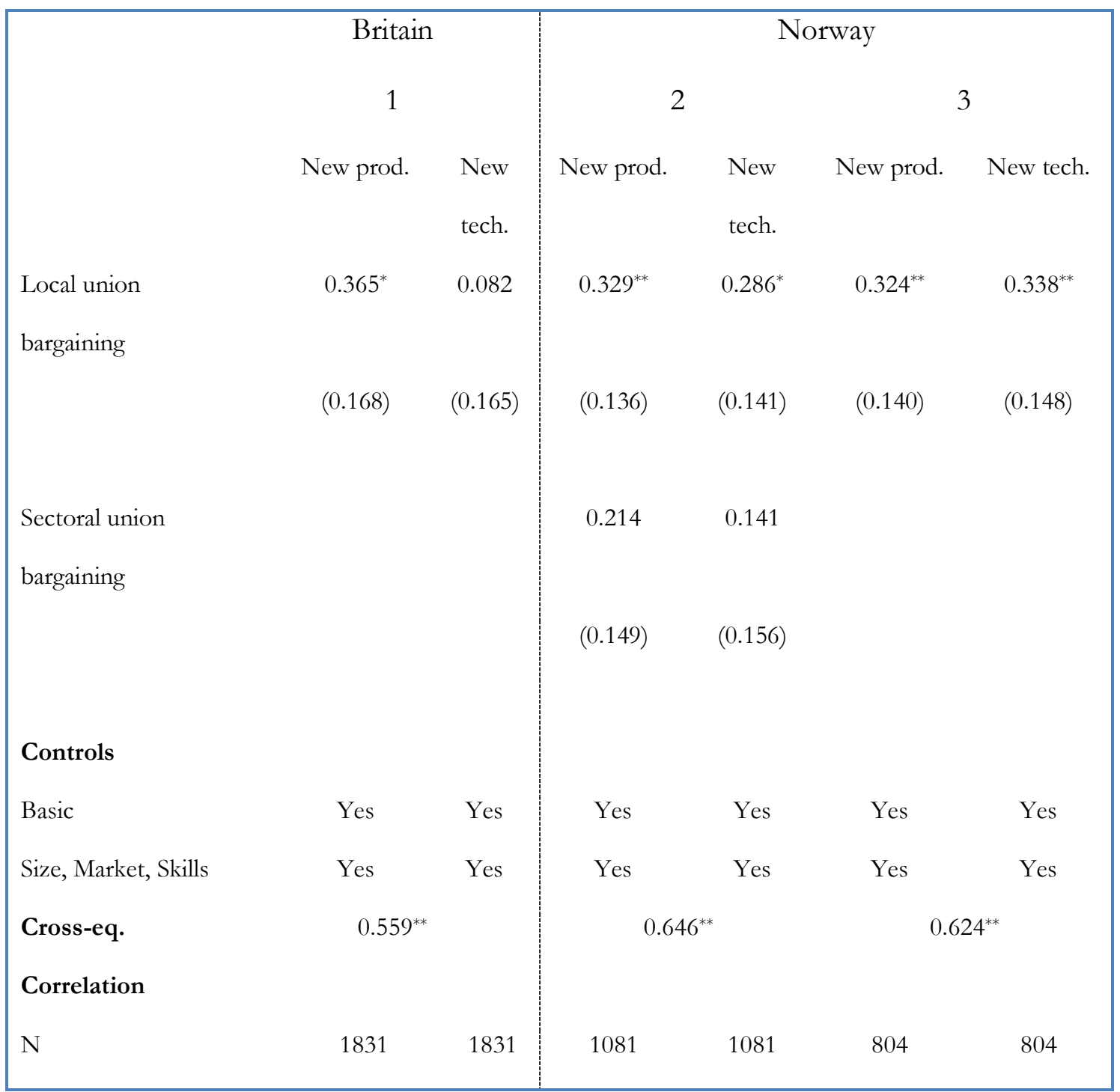

Note: Method: Bivariate Probit-system. Dependent variables: dummies for product innovation (new prod) and technological process innovation (new tech). Population: Private sector workplaces only. In Model 3, sectoral bargaining workplaces are discarded. Source: Workplace and Employment Relations Survey 2011 (UK) and Norwegian Workplace and Employment Relations Survey 2012. Each observation is weighted by the inverse of the sampling probability of the workplace adjusted for no-response. Control vectors: Basic: dummies for newly started business, weak competition, and 14 industry dummies; Size, Market, Skills: size (4 categories), dummies for increased or reduced demand, exporter, main occupation dummies. Robust standard errors are reported in parentheses. ${ }^{\mathrm{x}},{ }^{*}$ and ${ }^{* *}$ denote 10, 5 and 1 percent level of significance, respectively. 


\section{TABLE 5}

The impact of Bargaining on Innovations with Endogenous Bargaining

\begin{tabular}{|c|c|c|c|c|c|c|}
\hline & & Britain & & & Norway & \\
\hline & New prod. & New tech & Local. & New prod. & New tech & Local \\
\hline Local & 0.997 & 0.663 & & $1.355^{* *}$ & 0.224 & \\
\hline & $(0.672)$ & $(0.851)$ & & $(0.421)$ & $(0.428)$ & \\
\hline Employer organisation & & & $0.719^{* *}$ & & & $0.864^{* *}$ \\
\hline & & & $(0.294)$ & & & (0.198) \\
\hline Cross-equation correl & & & & & & \\
\hline New prod-new tech & & $0.581^{* *}$ & & & $0.494^{* *}$ & \\
\hline New prod-local & & -0.366 & & & -0.922 & \\
\hline New tech-local & & -0.334 & & & 0.073 & \\
\hline Controls & & & & & & \\
\hline Basic & Yes & Yes & Yes & Yes & Yes & Yes \\
\hline Size, Market, Skills & Yes & Yes & Yes & Yes & Yes & Yes \\
\hline $\mathrm{N}$ & 1831 & 1831 & 1831 & 807 & 807 & 807 \\
\hline
\end{tabular}

Note: Method: Trivariate Recursive Probit-system. Dependent variables: dummies for product innovation (new prod) and technological process innovation (new tech), and dummy for local bargaining (local). Private sector workplaces only. Source: Workplace and Employment Relations Survey 2011 (UK) and Norwegian Workplace and Employment Relations Survey 2012. Each observation is weighted by the inverse of the sampling probability of the workplace adjusted for no-response. Control vectors: Basic: dummies for newly started business, weak competition, and 14 industry dummies; Size, Market, Skills: size (4 categories), dummies for increased or reduced demand, exporter, main occupation dummies,. Robust standard errors are reported in parentheses. ${ }^{\mathrm{x}},{ }^{*}$ and ${ }^{* *}$ denote 10,5 and 1 percent level of significance, respectively. 
TABLE 6

Average marginal effects of bargaining on the predicted probabilities of innovations

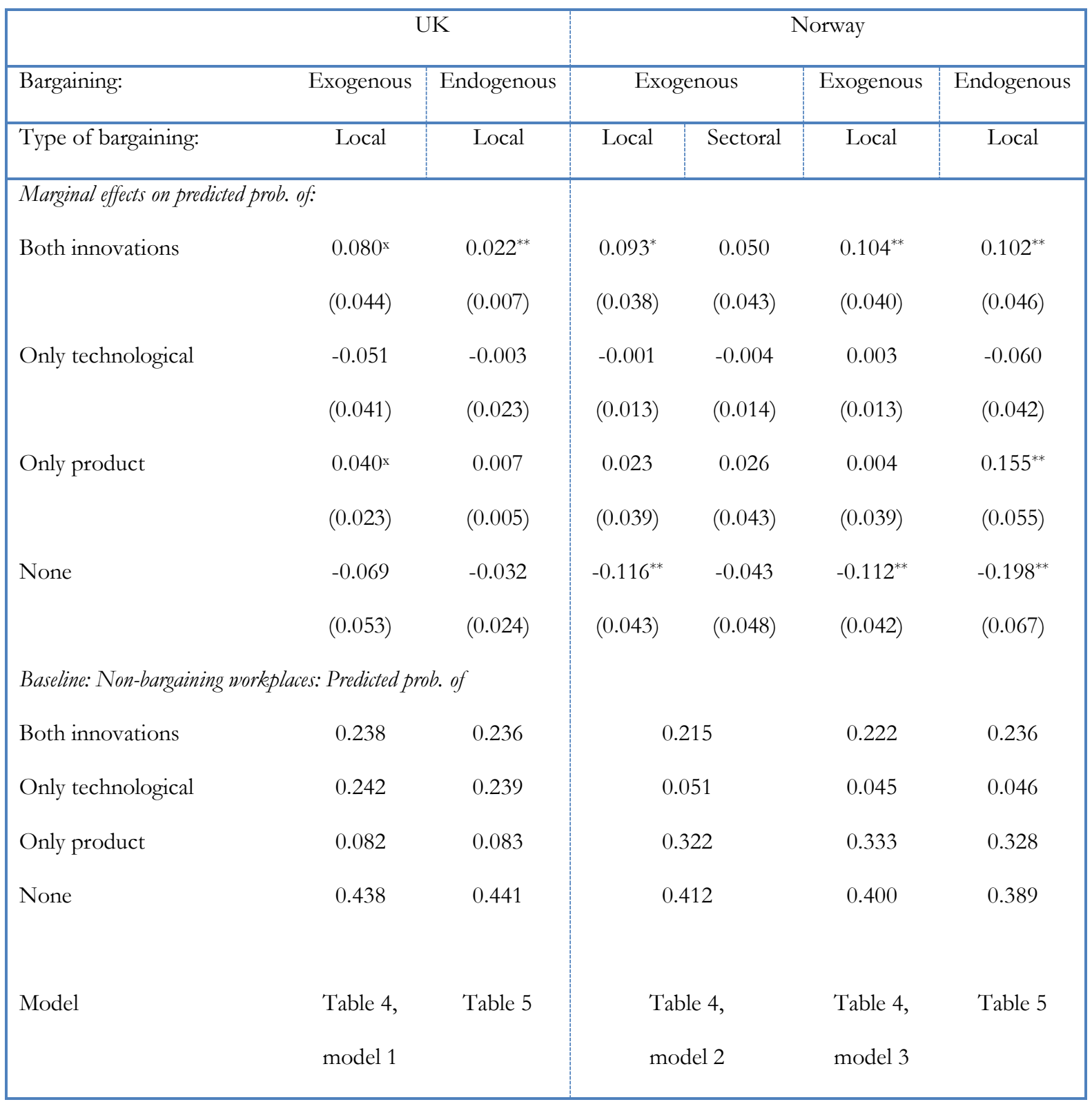

Note: See Table 4 and 5. Marginal effects of bargaining on predicted probabilities from bivariate Probit-regressions of Table 4 (models 1, 2 and 3) or from trivariate recursive Probit-regressions of Table 5. Both innovation denotes that both product and technological process innovation occurs. None denotes that neither product nor technological process innovation occurs. Only product and only technological denote that only product innovation or only technological process innovation occurs. Private sector workplaces only. Source: Workplace and Employment Relations Survey 2011 (UK) and Norwegian Workplace and Employment Relations Survey 2012. ${ }^{\mathrm{x}}{ }^{*}$ and ${ }^{* *}$ denote 10, 5 and 1 percent level of significance, respectively. 